\title{
Metformin triggers the intrinsic apoptotic response in human AGS gastric adenocarcinoma cells by activating AMPK and suppressing mTOR/AKT signaling
}

\author{
CHI-CHENG LU ${ }^{1,2}$, JO-HUA CHIANG ${ }^{3}$, FUU-JEN TSAI ${ }^{4,5,6}$, YUAN-MAN HSU $^{7}$, YU-NING JUAN ${ }^{8}$, \\ JAI-SING YANG $^{8}$ and HONG-YI CHIU $2,9,10$
}

\begin{abstract}
${ }^{1}$ Department of Sport Performance, National Taiwan University of Sport, Taichung 40404; ${ }^{2}$ Department of Pharmacy, Buddhist Tzu Chi General Hospital, Hualien 97002; ${ }^{3}$ Department of Nursing, Chung Jen Catholic Junior College, Chiayi 62241; ${ }^{4}$ Human Genetics Center, Department of Medical Research and ${ }^{5}$ Department of Medical Genetics, China Medical University Hospital, Taichung 40447; ${ }^{6}$ School of Chinese Medicine,

${ }^{7}$ Department of Biological Science and Technology, China Medical University, Taichung 40402;

${ }^{8}$ Department of Medical Research, China Medical University Hospital, China Medical University, Taichung 40447;

${ }^{9}$ Master and PhD Program in Pharmacology and Toxicology, School of Medicine, Tzu Chi University, Hualien 97004;

${ }^{10}$ General Education Center, Tzu Chi University of Science and Technology, Hualien 97005, Taiwan, R.O.C.
\end{abstract}

Received August 13, 2018; Accepted January 14, 2019

DOI: 10.3892/ijo.2019.4704

\begin{abstract}
Metformin is commonly used to treat patients with type 2 diabetes and is associated with a decreased risk of cancer. Previous studies have demonstrated that metformin can act alone or in synergy with certain anticancer agents to achieve anti-neoplastic effects on various types of tumors via adenosine monophosphate-activated protein kinase (AMPK) signaling. However, the role of metformin in AMPK-mediated apoptosis of human gastric cancer cells is poorly understood. In the current study, metformin exhibited a potent anti-proliferative effect and induced apoptotic characteristics in human AGS gastric adenocarcinoma cells, as demonstrated by MTT assay, morphological observation method, terminal deoxynucleotidyl transferase dUTP nick end labeling and caspase-3/7 assay kits. Western blot analysis demonstrated that treatment with metformin increased the phosphorylation of AMPK, and decreased the phosphorylation of AKT, mTOR and p70S6k. Compound C (an AMPK inhibitor) suppressed AMPK phosphorylation and significantly abrogated the
\end{abstract}

Correspondence to: Dr Jai-Sing Yang, Department of Medical Research, China Medical University Hospital, China Medical University, 2 Yude Road, Taichung 40447, Taiwan, R.O.C.

E-mail: jaisingyang@gmail.com

Dr Hong-Yi Chiu, Department of Pharmacy, Buddhist Tzu Chi General Hospital, Section 3, 707 Chung-Yang Road, Hualien 97002, Taiwan, R.O.C.

E-mail: hychiu@tzuchi.com.tw

Key words: metformin, adenosine monophosphate-activated protein kinase, mammalian target of rapamycin/AKT pathway, apoptosis, human gastric adenocarcinoma AGS cells effects of metformin on AGS cell viability. Metformin also reduced the phosphorylation of mitogen-activated protein kinases (ERK, JNK and p38). Additionally, metformin significantly increased the cellular ROS level and included loss of mitochondrial membrane potential $(\Delta \Psi \mathrm{m})$. Metformin altered apoptosis-associated signaling to downregulate the BAD phosphorylation and $\mathrm{Bcl}-2$, pro-caspase-9, pro-caspase-3 and pro-caspase-7 expression, and to upregulate BAD, cytochrome $c$, and Apaf-1 proteins levels in AGS cells. Furthermore, z-VAD-fmk (a pan-caspase inhibitor) was used to assess mitochondria-mediated caspase-dependent apoptosis in metformin-treated AGS cells. The findings demonstrated that metformin induced AMPK-mediated apoptosis, making it appealing for development as a novel anticancer drug for the treating gastric cancer.

\section{Introduction}

Gastric cancer is a leading cause of mortality worldwide according to the World Health Organization, accounting for 754,000 mortalities in 2015 (1). According to the 2017 annual report by the Ministry of Health and Welfare in Taiwan, gastric cancer is the 7th leading cause of cancer-associated mortality. The mortality rate of gastric cancer was 9.8 per 100,000 of the population (2). The major risk factors of gastric cancer are Helicobacter pylori infection, and dietary and environmental factors $(3,4)$. The overall 5 -year relative survival rate of patients with gastric cancer in the United States is $\sim 31 \%$ (5). Paclitaxel, carboplatin, cisplatin, 5-fluorouracil, capecitabine and leucovorin are recognized as the most effective agents against gastric cancer $(6,7)$. Apart from surgery, no satisfactory chemotherapeutic strategies are currently available for gastric cancer, and novel effective therapies are required to improve gastric anticancer treatment. 
Metformin, a biguanide drug, is the first line clinical agent for type 2 diabetes mellitus (T2D) treatment $(8,9)$. The pharmacological mechanism of metformin is to downregulate blood glucose levels to enhance insulin sensitivity in the liver and peripheral tissues (stimulating glucose uptake into muscles and/or increasing fatty acid oxidation in adipose tissue) by activation of adenosine monophosphate (AMP)-activated protein kinase (AMPK) signaling $(10,11)$. In addition, the effectiveness of metformin involves reduced hepatic gluconeogenesis $(11,12)$. The epidemiological studies have suggested that the use of metformin is associated with a decreased incidence of cancer, and improved prognosis and cancer-associated mortality in patients with T2D $(13,14)$. The anticancer effects of metformin have been reported in breast $(15,16)$, colorectal (17), liver (18), cervical (19), endometrial (20), gastric (21), lung (22), ovarian (23), prostate (24), pancreatic (25) and renal (26) cancer. Various studies have demonstrated that the anticancer mechanisms of metformin are mediated via the AMPK/mammalian target of rapamycin (mTOR) cascade, and the signaling is dependent on AMPK activation leading to inhibition of mTOR that represses protein synthesis, cell proliferation, cell cycle progression and apoptotic cell death (27-29). A previous study demonstrated that metformin inhibits the proliferation and metastasis of SGC-7901 and BGC-823 gastric cancer cells by suppressing hypoxia-inducible factor $1 \alpha /$ pyruvate kinase M1/2 signaling (30). Apoptosis (type I programmed cell death) is a tightly regulated biological process $(31,32)$. Anticancer agents that trigger the apoptotic pathway in cancer cells may be of potential clinical use (33). Metformin has been reported to inhibit cell proliferation in human gastric cancer cell lines, including MKN45, MKN47, MKN-28, SGC-7901 and BGC-823, and cancer stem cells $(34,35)$. Additionally, metformin reduces metastasis of human gastric cancer AGS cells by inhibiting epithelial-mesenchymal transition (EMT) in a glucose-independent manner (36). Although the mechanism responsible for the anti-metastatic action of metformin has been investigated, its role of AMPK-mediated apoptotic machinery in gastric cancer cells remains unclear. In the current study, the anti-proliferation effect of metformin cells and underlying apoptotic mechanism was investigated using human gastric cancer AGS cells in vitro.

\section{Materials and methods}

Chemicals and materials. Metformin hydrochloride, thiazolyl blue tetrazolium bromide (MTT), In Situ Cell Death Detection kit (fluorescein), compound C, carbobenzoxyvalyl-alanyl-aspartyl fluoromethyl ketone (z-VAD-fmk), and all other chemicals and reagents were purchased from Sigma-Aldrich (Merck KGaA, Darmstadt, Germany), unless otherwise stated. All primary antibodies, anti-mouse and anti-rabbit immunoglobulin (Ig)G horseradish peroxidase (HRP)-linked secondary antibodies were obtained from GeneTex International Corporation (Hsinchu, Taiwan). Muse Caspase-3/7 Assay Kit was obtained from Merck KGaA. 2',7'-Dichlorodihydrofluorescein diacetate ( $\mathrm{H}_{2}$ DCFDA) and 3,3'-dihexyloxacarbocyanine iodide $\left[\mathrm{DiOC}_{6}(3)\right]$ were obtained from Molecular Probes (Thermo Fisher Scientific, Inc. Waltham, MA, USA). Ham's Nutrient Mixture F12 medium, minimum essential medium, fetal bovine serum (FBS),
L-glutamine, penicillin/streptomycin and trypsin-EDTA were purchased from HyClone (GE Healthcare Life Sciences, Logan, UT, USA). Mitochondria/Cytosol Fractionation Kit was bought from BioVision, Inc. (Milpitas, CA, USA).

Cell culture. The human AGS gastric adenocarcinoma cell line was purchased from the Bioresource Collection and Research Center (Hsinchu, Taiwan) and cultured in Ham's Nutrient Mixture F12 medium supplemented with 10\% FBS, 2 mM L-glutamine, $100 \mathrm{U} / \mathrm{ml}$ penicillin, and $100 \mu \mathrm{g} / \mathrm{ml}$ streptomycin. The normal human colon CCD 841 CoN cells (CRL-1790) and embryonic lung fibroblast HEL 299 cells (CCL-137) were purchased from the American Type Culture Collection (ATCC; Manassas, VA, USA) and cultured in minimum essential medium containing 10\% FBS, $100 \mathrm{U} / \mathrm{ml}$ penicillin and $100 \mu \mathrm{g} / \mathrm{ml}$ streptomycin. Normal 293 cells (CRL-1573) were purchased from the ATCC and maintained in minimum essential medium supplemented with $10 \% \mathrm{FBS}, 0.1 \mathrm{mM}$ non-essential amino acids, $1.0 \mathrm{mM}$ sodium pyruvate, $100 \mathrm{U} / \mathrm{ml}$ penicillin and $100 \mu \mathrm{g} / \mathrm{ml}$ streptomycin. All of the cells were maintained at $37^{\circ} \mathrm{C}$ in a humidified atmosphere incubator with $5 \% \mathrm{CO}_{2}$.

Cytotoxicity assay. The cytotoxic effect of metformin was detected in an MTT assay, as described previously (37). In brief, AGS, CCD 841 CoN, HEL 299 and 293 cells (1x104 cells/well) were cultured in 96-well plates and exposed to various concentrations $(10,20,30,40$ and $50 \mathrm{mM})$ of metformin for 12,24 or $48 \mathrm{~h}$ after pretreatment with or without $10 \mu \mathrm{M}$ compound C (an AMPK inhibitor), or $10 \mu \mathrm{M} z$-VAD-fmk (a pan-caspase inhibitor) for $2 \mathrm{~h}$. Following treatments, $10 \mu \mathrm{l}$ MTT solution $(5 \mathrm{mg} / \mathrm{ml})$ was added per well, and the cells were cultured for an additional $3 \mathrm{~h}$. The medium was then removed, and the formation of formazan was solubilized using $100 \mu$ l dimethyl sulfoxide. The absorbance was detected using an ELISA plate reader at $570 \mathrm{~nm}$ in a spectrophotometer, as previously described $(38,39)$.

Morphological observation. AGS cells ( $1 \times 10^{5}$ cells/well) were plated onto 12-well plates and then treated with or without 10 , 20,30, 40 and $50 \mathrm{mM}$ metformin for 12, 24 and $48 \mathrm{~h}$. The cells were subsequently observed and images using a phase-contrast microscope at a magnification of $\mathrm{x} 200$.

Apoptosis analysis by flow cytometry. AGS cells $\left(1 \times 10^{5}\right.$ cells $\left./ \mathrm{ml}\right)$ were cultured with or without $10,20,30$ and $40 \mathrm{mM}$ metformin for $48 \mathrm{~h}$. The cells were subsequently washed with PBS and harvested. To detect apoptosis by flow cytometry (BD FACSCalibur Flow Cytometer; BD Biosciences; Becton-Dickinson Co., Franklin Lakes, NJ, USA), the cells were then stained with the In Situ Cell Death Detection Kit, Fluorescein (Sigma-Aldrich; Merck KGaA), following the manufacturer's instructions. The terminal deoxynucleotidyl transferase-mediated dUTP nick end labeling (TUNEL)-positive cells were quantified using the BD CellQuest Pro Software version 5.1 (BD Biosciences; Becton-Dickinson and Company), as previously described (38).

Caspase-3/7 activity. AGS cells ( $5 \times 10^{6}$ cells/75T flask) were incubated with or without 10, 20, 30 and $40 \mathrm{mM}$ metformin 
for $48 \mathrm{~h}$. The cells were collected by centrifugation at $400 \mathrm{x} \mathrm{g}$ prior to incubation with the working solution provided in the Muse Caspase-3/7 Assay Kit (Merck KGaA), according to the manufacturer's protocol.

Western blotting. AGS cells $\left(5 \times 10^{6}\right.$ cells per $75 \mathrm{~T}$ flask) were incubated with $0,10,20$ and $30 \mathrm{mM}$ metformin for the indicated period of time ( $12 \mathrm{or} 48 \mathrm{~h}$ ) following pretreatment with or without $10 \mu \mathrm{M}$ compound $\mathrm{C}$ for $2 \mathrm{~h}$. At the end of the exposure period, the cells were lysed using Trident radioimmunoprecipitation assay lysis buffer (GeneTex International Corporation) to extract total protein. The cytosolic and mitochondrial fractions were prepared via the Mitochondria/Cytosol Fractionation Kit (BioVision, Inc.) according to the manufacturer's instructions. The protein concentration was determined using the Pierce bicinchoninic acid protein assay kit (Thermo Fisher Scientific, Inc.). A protein sample $(40 \mu \mathrm{g})$ was loaded in each well of a 10-12\% polyacrylamide gel, separated by SDS-PAGE and transferred to the Immobilon-P Transfer membrane (Merck KGaA) for $1 \mathrm{~h}$, as previously described (40). The membrane was blocked with 5\% skim milk in Tris-buffered saline with $0.1 \%$ Tween-20 (TBST) and incubated with the following primary antibodies (GeneTex International Corporation): Phospho (p)-AMPK (cat no. GTX52341), AMPK (cat no. GTX112998), p-protein kinase B (AKT; cat. no. GTX28932), AKT (cat. no. GTX121937), p-mTOR (cat. no. GTX50258), mTOR (cat. no. GTX101557), p-ribosomal protein S6 kinase B1 (p70S6K; cat. no. GTX50304), p70S6K (cat. no. GTX103174), p-extracellular signal regulated kinase (ERK; cat. no. GTX59568), ERK (cat. no. GTX59618), p-c-Jun N-terminal kinase (JNK; cat. no. GTX52326), JNK (cat. no. GTX52360), p-p38 (cat. no. GTX48614), p38 (cat. no. GTX110720), p-Bcl-2-associated agonist of cell death (BAD; Ser136; cat. no.GTX50136), BAD (cat. no. GTX130108), B cell lymphoma-2 (Bcl-2; cat. no. GTX100064), cytochrome $c$ (cat. no. GTX108585), apoptotic protease-activating factor-1 (Apaf-1; cat. no. GTX22000), caspase-9 (cat. no. GTX112888), caspase-3 (cat.no. GTX110543), caspase-7 (cat. no. GTX22301; all 1:1,000 dilution), $\beta$-actin (cat. no. GTX109639; 1:5,000 dilution), GAPDH (cat. no. GTX100118; 1:5,000 dilution), and cytochrome $c$ oxidase subunit IV isoform 1 (COX IV; cat. no. GTX114330; 1:2,000 dilution) at $4^{\circ} \mathrm{C}$ overnight. The next day, the membrane was washed with TBST and incubated with the appropriate anti-rabbit (cat. no. GTX213110-01) and anti-mouse (cat. no. GTX213111-01) IgG HRP-linked antibodies (1:10,000 dilution) for $1 \mathrm{~h}$ at room temperature. An enhanced chemiluminescence kit (Immobilon Western Chemiluminescent HRP substrate; Merck KGaA) was used to visualize protein bands, and protein band densitometry was performed using ImageJ software (version 1.47; National Institutes of Health, Bethesda, MD, USA).

Measuring reactive oxygen species (ROS) and the mitochondrial membrane potential $(\Delta \Psi$ m) viaflow cytometry. AGS cells $\left(2 \times 10^{5}\right.$ cells $\left./ \mathrm{ml}\right)$ seeded in 12 -well plates were exposed to $0,10,20,30$ and $40 \mathrm{mM}$ metformin for $48 \mathrm{~h}$. Subsequently, the cells were harvested and centrifuged at $400 \mathrm{x} \mathrm{g}$ for $5 \mathrm{~min}$, and the cell pellet was suspended in $500 \mu \mathrm{l}$ $\mathrm{H}_{2}$ DCFDA (an ROS indicator dye, $\left.10 \mu \mathrm{M}\right)$ or $\mathrm{DiOC}_{6}(3)(\mathrm{a} \Delta \Psi \mathrm{m}$ probe, $50 \mathrm{nM}$ ) staining solution at $37^{\circ} \mathrm{C}$ for $30 \mathrm{~min}$. The cells

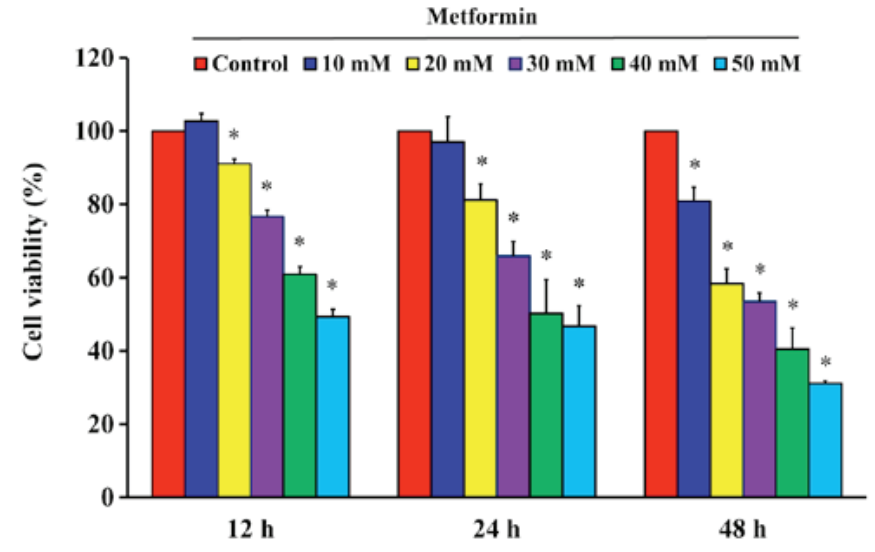

Figure 1. Effect(s) of metformin on the viability of AGS cells. The cells were exposed to $0,10,20,30,40$ and $50 \mathrm{mM}$ of metformin for 12, 24 and $48 \mathrm{~h}$. The viability of AGS cells was detected by the MTT assay. The values are presented as the mean \pm standard deviation of triplicates within three representative experiments. ${ }^{*} \mathrm{P}<0.05$ vs. untreated control.

were then analyzed using flow cytometry (BD FACSCalibur Flow Cytometer; BD Biosciences; Becton-Dickinson Co.), as previously described $(40,41)$.

Statistical analysis. All results are presented as the mean \pm standard deviation of triplicates. The data were statistically analyzed by one-way analysis of variance followed by Dunnett's test using SPSS software version 16.0 (SPSS, Inc., Chicago, IL, USA). $\mathrm{P}<0.05$ was considered to indicate a statistically significant difference.

\section{Results}

Metformin is cytotoxic to human gastric cancer AGS cells. After cells were treated with 10, 20, 30, 40 and $50 \mathrm{mM}$ metformin for 12, 24 and $48 \mathrm{~h}$, the MTT assay was used to analyze cell viability. The results demonstrated that metformin significantly reduced cell viability after incubation with $20 \mathrm{mM}$ metformin for $12 \mathrm{~h}$; furthermore, the reductions of viability were time- and concentration-dependent (Fig. 1). The cells were treated with metformin prior to morphological characterization. The marked morphologic alterations (such as cell shrinkage, nuclear condensation, membrane blebbing and rounding) were present in a time- and concentration-dependent manner in AGS cells (Fig. 2). Thus, metformin suppressed AGS cell growth via induction of apoptotic death. Additionally, the data demonstrated that metformin $(0,10,20,30$ and $50 \mathrm{mM})$ after exposure for $48 \mathrm{~h}$ had no significant effect of the viability of normal colon CCD $841 \mathrm{CoN}$ cells (Fig. 3A), embryonic lung HEL 299 cells (Fig. 3B) and 293 cells (Fig. 3C). This suggested that metformin may have lower toxicity in normal cells (CCD 841 CoN, HEL 299 and 293 cells) compared with cancer cells.

Metformin promotes apoptosis of AGS cells. Following treatment of AGS cells with 10,20,30 and $40 \mathrm{mM}$ metformin for $48 \mathrm{~h}$, a TUNEL assay was used to detect DNA breaks, which are a direct apoptotic response. The results demonstrated that metformin at 20, 30 and $40 \mathrm{mM}$ concentration-dependently produced double-stranded DNA fragmentation (a unique 


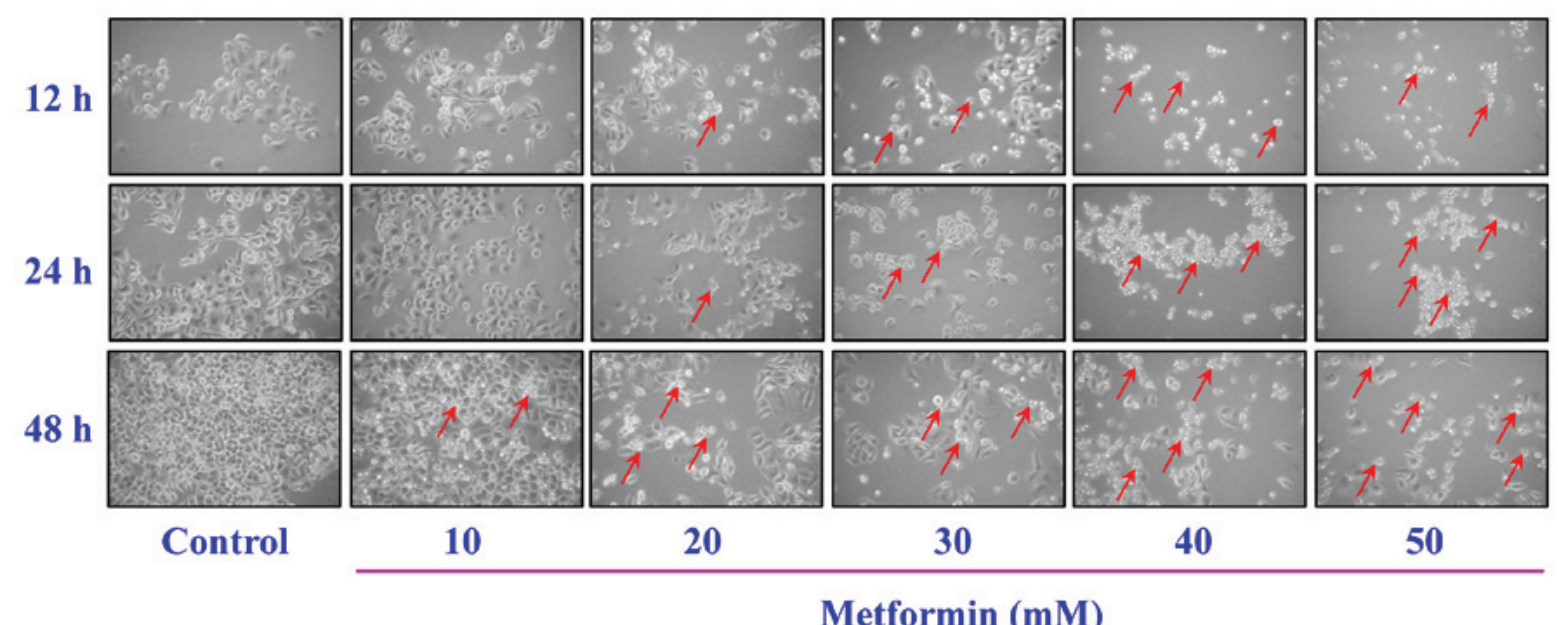

Figure 2. Effect(s) of metformin on apoptotic morphological changes of AGS cells. The cells were treated with or without 10, 20,30,40 and 50 mM of metformin for 12, 24 and $48 \mathrm{~h}$. The cells were observed and imaged via a phase-contrast microscope at x 200 magnification. Arrows indicate apoptotic AGS cells.
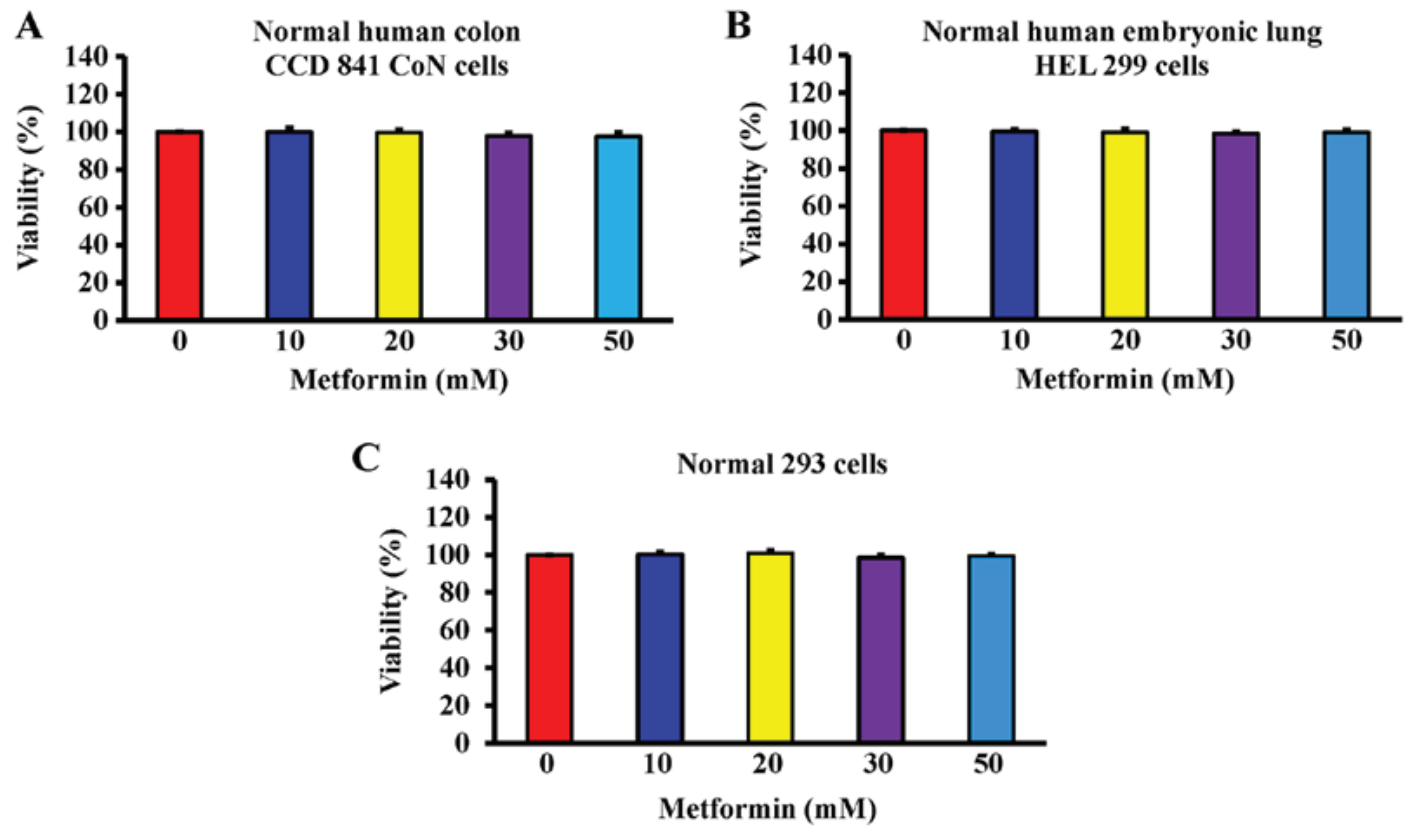

Figure 3. Effect(s) of metformin on the viability of normal cells. (A) Normal human colon CCD 841 CoN cells, (B) embryonic lung HEL 299 cells and (C) 293 cells were treated with $0,10,20,30$ and $50 \mathrm{mM}$ of metformin for $48 \mathrm{~h}$. The cell viability was determined via the MTT assay. The values are presented as the mean \pm standard deviation of triplicates within three representative experiments.

biochemical hallmark of apoptosis) and enhanced the number of TUNEL-positive cells (Fig. 4A), indicating that metformin induces AGS cell apoptosis. To determine whether caspase-3/7 are involved in the metformin-induced apoptosis, caspase-3/7 activity was analyzed using a Muse Caspase-3/7 Assay kit. The data indicated that metformin $(20,30$, and $40 \mathrm{mM}$ ) significantly enhanced the activity of caspase- $3 / 7$ in a concentration-dependent manner (Fig. 4B). These findings demonstrate that the ability of metformin to trigger apoptosis of AGS cell may be caspase-3/7-dependent.

AMPK pathway contributes to metformin-induced cytotoxicity and apoptosis in AGS cells. AMPK and AKT/mTOR signaling are usually involved in the regulation of cell proliferation and apoptosis (42). AGS cells were treated with 10,20 and $30 \mathrm{mM}$ metformin for $12 \mathrm{~h}$, or pretreated with or without $10 \mu \mathrm{M}$ compound C (an AMPK inhibitor) for $2 \mathrm{~h}$ prior to metformin exposure. The findings indicated that metformin stimulated phosphorylation of AMPK at Thr172, but there was no alteration in AMPK expression in AGS cells (Fig. 5A). To confirm whether the AMPK pathway has a key molecular role in metformin-treated AGS cells, an AMPK inhibitor, compound C, was applied, and the level of p-AMPK and cell viability were analyzed by western blotting and an MTT assay, respectively. The data demonstrated that compound $\mathrm{C}$ suppressed phosphorylation of AMPK (Fig. 5B) and significantly reversed the effect of metformin on cell viability compared with metformin treatment only (Fig. 5C). Thus, metformin-induced apoptosis is mediated via modulated AMPK signaling in AGS cells. To further clarify 

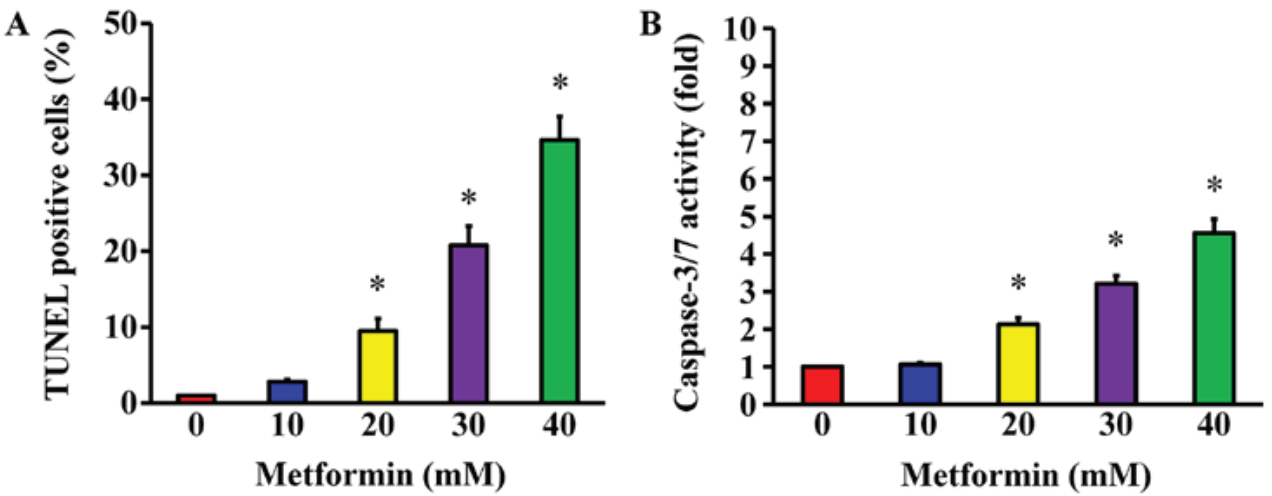

Figure 4. Effect(s) of metformin on apoptotic evidence and caspase-3/7 activity of AGS cells. The cells were incubated with 0, 10, 20,30 and 40 mM of metformin for 48 h. (A) TUNEL-positive cells were determined by flow cytometry, as described in the Materials and Methods section. (B) Caspase-3/7 activities were analyzed via Muse Caspase-3/7 Assay Kit. The values are presented as the mean \pm standard deviation of triplicates. ${ }^{*} \mathrm{P}<0.05$ vs. untreated control. TUNEL, terminal deoxynucleotidyl transferase-mediated dUTP nick end labeling.

the downstream signaling involved, cells were treated with metformin and harvested for western blot analysis to detect the phosphorylation of AKT (p-AKT), mTOR (p-mTOR), and p70S6K (p-p70S6K). The results demonstrated that metformin decreased the phosphorylation of AKT, mTOR, and p70S6K, whereas metformin did not affect the protein expression in AGS cells (Fig. 5D). These data indicate that metformin enhances apoptosis potentially by targeting AMPK and AKT/mTOR pathway in AGS cells.

Metformin inhibits mitogen-activated protein kinase (MAPK) signaling in AGS cells. To assess whether MAPKs (ERK, JNK and p38) contribute to metformin-induced apoptosis, the cells were exposed to metformin and MAPK proteins were detected via western blot analysis. MAPK signals are essential for induction of apoptosis $(43,44)$. Treating AGS cells with metformin markedly attenuated the phosphorylation of ERK, JNK and p38 (Fig. 6), with no obvious alterations in ERK, JNK and p38 MAPK protein expression. The results demonstrate that the apoptotic mechanism of metformin may involve ERK, JNK, and p38 MAPK-regulated pathways in AGS cells.

Metformin promotes ROS production and $\triangle \Psi m$ in $A G S$ cells. To determine whether metformin-induced apoptosis is mitochondria-dependent, ROS production and the $\Delta \Psi \mathrm{m}$ were measured in AGS cells. The cells were treated with metformin at various concentrations $(10,20,30$ and $40 \mathrm{mM})$ for $48 \mathrm{~h}$. The levels of ROS production and $\Delta \Psi \mathrm{m}$ were measured using the specific fluorochromes $\mathrm{H}_{2} \mathrm{DCFDA}$ and $\mathrm{DiOC}_{6}(3)$, respectively, via flow cytometry. The results revealed that metformin increased the production of ROS (Fig. 7A) and decreased the $\Delta \Psi \mathrm{m}$ (Fig. 7B) in AGS cells. Furthermore, these effects were concentration-dependent.

Metformin induces apoptosis via the intrinsic signaling pathway in AGS cells. To determine the effect of metformin on apoptosis, the expression of Bcl-2 family proteins and mitochondria-mediated proteins were analyzed in metformin-treated AGS cells. Western blot analysis indicated that metformin treatment reduced the phosphorylation of BAD and expression of $\mathrm{Bcl}-2$, but metformin induced total BAD expression in AGS cells (Fig. 8A). Furthermore, metformin increased the protein expression of Apaf-1 (Fig. 8B) and reduced the expression of pro-caspase- 9 , pro-caspase-3 and pro-caspase-7 expression (Fig. 8C) in AGS cells. Furthermore, metformin caused an increase in cytochrome $c$ in cytoplasmic extracts (Fig. 8D); however, mitochondrial cytochrome $c$ levels were decreased in AGS cells (Fig. 8D). Notably, z-VAD-fmk, a pan-caspase inhibitor, significantly abrogated the effect of metformin on viability compared with metformin-treated cells (Fig. 8E), suggesting that mitochondria-mediated caspase-dependent apoptosis may be required for the cytotoxic effect of metformin on human gastric adenocarcinoma AGS cells (Fig. 9).

\section{Discussion}

Metformin, an oral biguanide agent that was FDA-approved in 1957, has been used as a safe and cost-efficient treatment for T2D worldwide $(45,46)$. Numerous studies have indicated that long-term administration of metformin reduces the risk of various types of cancer, including breast, colon and endometrial cancer, and glioma (13-17,20,47). Recently, Li et al (48) demonstrated that metformin can increase the survival rate of diabetic patients with gastric cancer. Previous studies have demonstrated that metformin inhibits cell proliferation and induces cell death in various types of cancer cells, including HepG2 hepatoma cells (49), SKOV3, A2780 and ES2 ovarian cancer cells $(50,51)$, paclitaxel-resistant A2780-PR and cisplatin-resistant ACRP cells (52), B16F10 melanoma cells (53), Dami and MEG-01 megakaryoblastic cancer cells (54), and CAL 27, CAL 33, and UMSCC47 head and neck carcinoma cells (55). Furthermore, metformin also suppresses the cell metastasis of MG63 and U-2 OS osteosarcoma cells (56), SiHa and HeLa cervical cancer cells (57), and EC109 esophageal squamous cells carcinoma cells (58). In addition, synergistic interactions with metformin enhance antitumor activities; for example, sirolimus in colorectal cancer cells (59), chrysin in breast cancer (60), quercetin in prostate cancer cells (24), rapamycin in pancreatic cancer cells (61), vincristine in leukemia cancer cells (62), curcumin in hepatocellular carcinoma cells (63), cisplatin in gallbladder cancer cells (64). Metformin at 10-100 $\mathrm{mM}$ has been reported to dose- and time-dependently inhibit cell proliferation in 
A

\begin{tabular}{|c|c|c|c|c|}
\hline \multirow[t]{2}{*}{ A } & \multicolumn{4}{|c|}{ Metformin (m M) } \\
\hline & 0 & 10 & 20 & 30 \\
\hline \multirow{2}{*}{ p-AMPK } & & - & - & - \\
\hline & 1.0 & 1.5 & 2.3 & 2.4 \\
\hline \multirow{2}{*}{ AMIPK } & 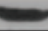 & $=$ & $\rightarrow$ & 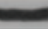 \\
\hline & 1.0 & 1.0 & 1.0 & 1.0 \\
\hline
\end{tabular}

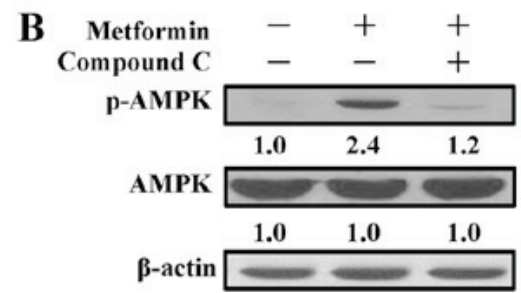

C

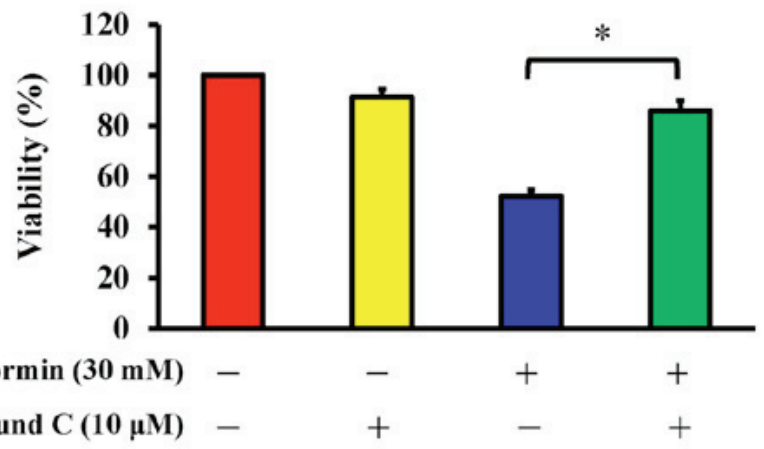

D

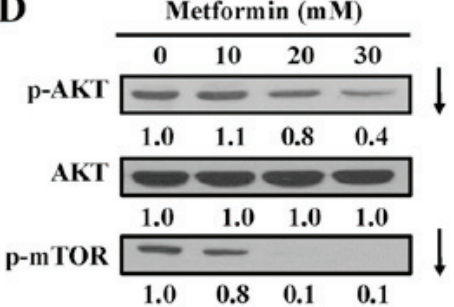

mTOR

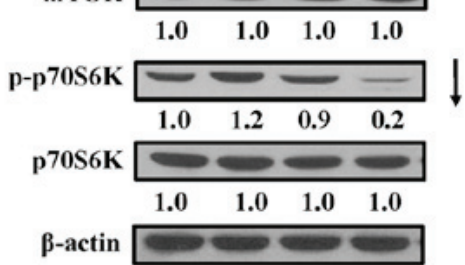

Figure 5. Effect(s) of metformin on AMPK signaling and its downstream molecules of AGS cells. (A) Cells were exposed to 0, 10, 20 and 30 mM metformin for $12 \mathrm{~h}$ and protein levels of p-AMPK and AMPK were detected. (B) Cells were cultured without or with 10, 20 and $30 \mathrm{mM}$ metformin for $12 \mathrm{~h}$ following pre-incubation with or without $10 \mu \mathrm{M}$ compound $\mathrm{C}$ (an AMPK inhibitor) for $2 \mathrm{~h}$ and protein levels of p-AMPK and AMPK were detected. (C) Cells were treated without or with $30 \mathrm{mM}$ metformin for $48 \mathrm{~h}$ after pre-incubation with or without $10 \mu \mathrm{M}$ compound C for $2 \mathrm{~h}$. Cell viability was estimated by the MTT assay. The values are presented as the mean \pm standard deviation of triplicates. ${ }^{*} \mathrm{P}<0.05$ vs. metformin-treated only. (D) Cells were treated without or with 10 , 20 and $30 \mathrm{mM}$ of metformin for $12 \mathrm{~h}$ and protein levels of p-AKT, AKT, p-mTOR, mTOR, p-p70S6K and p70S6K were determined by immunoblot analysis $\beta$-actin was an internal loading control. p-, phospho; AMPK, adenosine monophosphate-activated protein kinase; AKT, protein kinase B; mTOR, mammalian target of rapamycin; p70S6K, ribosomal protein S6 kinase B1.

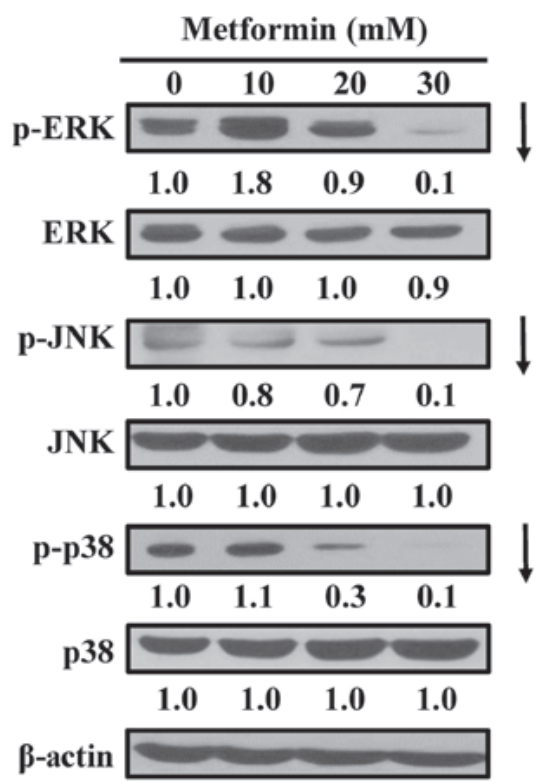

Figure 6. Effect(s) of metformin on ERK, JNK and p38 pathways of AGS cells. The cells were incubated with $0,10,20$ and $30 \mathrm{mM}$ of metformin for $12 \mathrm{~h}$, and whole-cell lysates were then collected. Cell fractions were individually probed with anti-p-ERK, anti-ERK, anti-p-JNK, anti-JNK, anti-p-p38 and anti-p38 by western blotting analysis. $\beta$-Actin was an internal loading control. p-, phospho; ERK, extracellular signal-regulated kinase; JNK, c-Jun N-terminal kinase.

AGS cells in low-and high-glucose conditioned media (36). In the current study, the results revealed that treatment with $50 \mathrm{mM}$ metformin significantly inhibited the viability of AGS cells (Video $\mathrm{S} 1$ ). These results are in accordance with those from a study by Valaee et al (36), indicating that metformin suppresses the proliferation and viability of AGS cells. An in vivo study also demonstrated that metformin did not cause apparent toxicity in nude mice bearing with hepatocellular carcinoma tumors (65). The findings also revealed that metformin has no effect on viability in normal cells (human colon CCD 841 CoN, embryonic lung HEL 299 and 293 cells).

AMPK is a serine/threonine protein kinase $(10,11)$. AMPK signaling is a cellular energy and nutrient sensor, and also has an essential role in metabolic pathways $(27,28)$. AMPK activation inhibits protein synthesis and cell proliferation $(11,28)$. Furthermore, activation of the AMPK signaling inhibits tumor growth (27,28). Metformin suppresses the respiratory complex I, which increases the adenosine diphosphate/adenosine triphosphate (ATP) and AMP/ATP ratios, and attenuates of ATP production and oxidative phosphorylation, resulting reduced cellular ATP and activation of AMPK $(10,12)$. Zakikhani et al (66) demonstrated that metformin attenuates the proliferation of breast cancer cells through the activation of AMPK, causing the inhibition of mTOR signaling. Metformin activates the expression of AMPK and inhibits phosphorylation of mTOR, downstream p70S6K, and eIF4E-binding proteins (67). The present study demonstrated that metformin-induced apoptosis was accompanied by upregulation AMPK Thr172 phosphorylation, and downregulation of AKT (Ser473), mTOR (Ser2448) and p70S6K (Ser424) phosphorylation. The data also demonstrated that attenuation of AMPK signaling using an AMPK inhibitor (compound C) abrogated the effects of metformin on the viability of AGS cells.

MAPKs include three main molecules, ERK, JNK and p38, which have various biological functions, including apoptotic mechanisms, cell cycle regulation and cell 

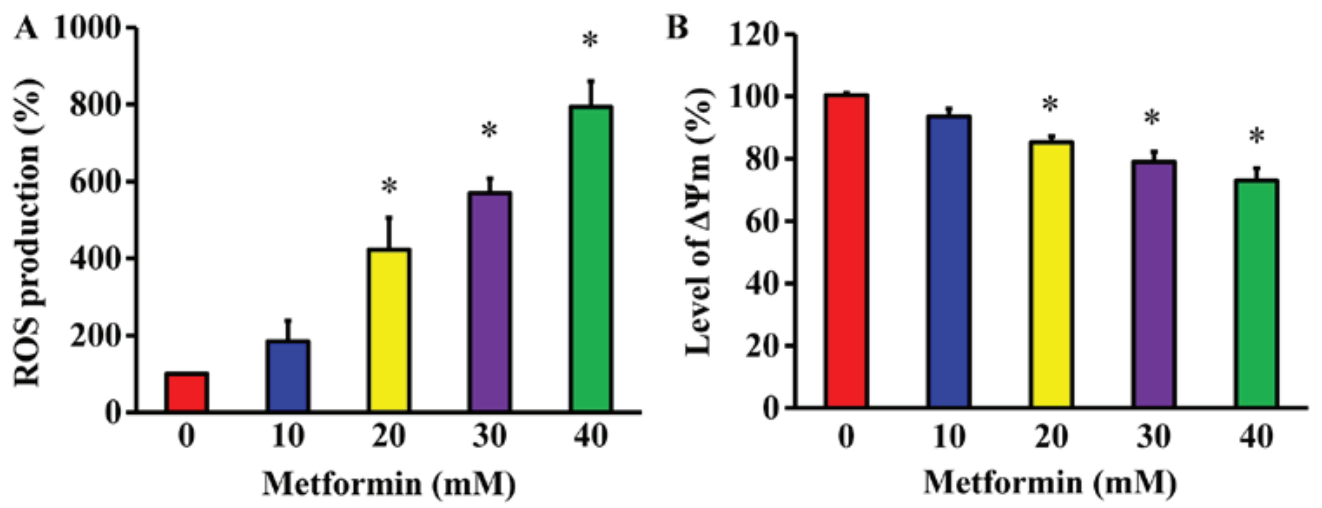

Figure 7. Effect(s) of metformin on ROS production and $\Delta \Psi \mathrm{m}$ in AGS cells. Cells were incubated with or without $10,20,30$ and $40 \mathrm{mM}$ of metformin for $48 \mathrm{~h}$ (A) ROS levels were measured by staining with 2',7'-dichlorodihydrofluorescein diacetate and (B) the level of $\Delta \Psi \mathrm{m}$ was assessed with 3,3'-dihexyloxacarbocyanine iodide by flow cytometry. The values are presented as the mean \pm standard deviation of triplicates. ${ }^{*} \mathrm{P}<0.05$ vs. untreated control. ROS, reactive oxygen species; $\Delta \Psi \mathrm{m}$, mitochondrial membrane potential.

A

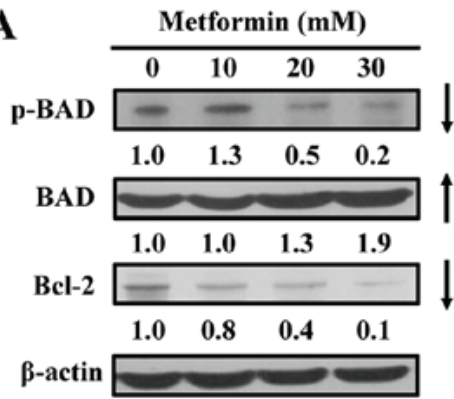

D

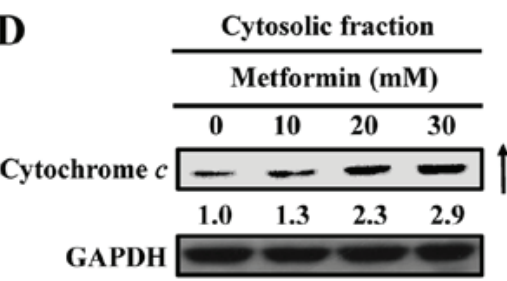

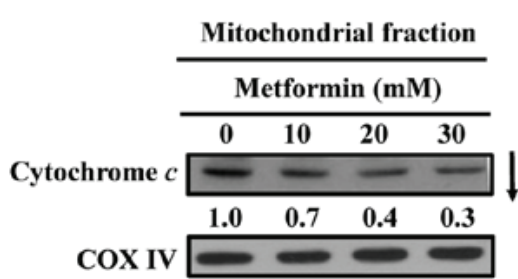

B

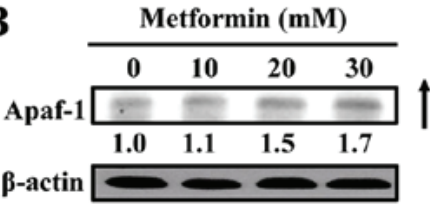

$\mathbf{E}$

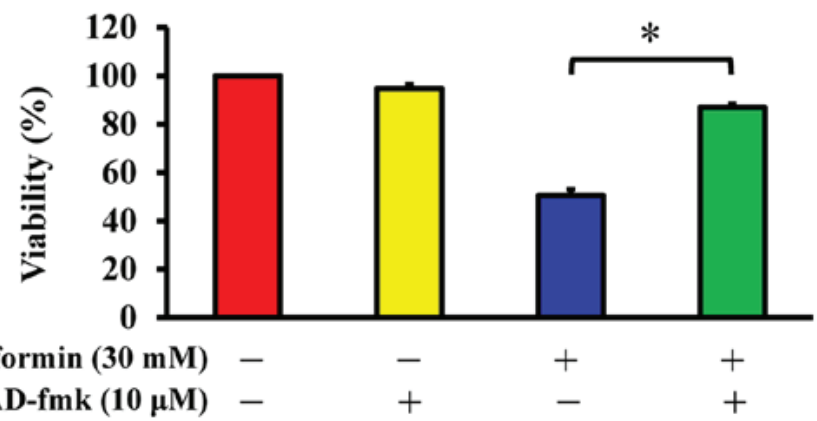

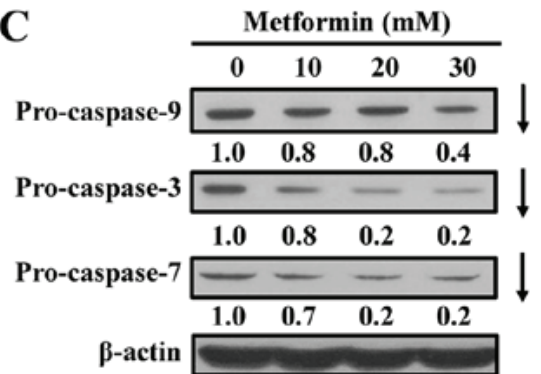

Figure 8. Effect(s) of metformin on mitochondria-mediated caspase-dependent apoptotic signaling of AGS cells. The cells were treated with 0 , 10, 20 and $30 \mathrm{mM}$ of metformin for $48 \mathrm{~h}$, and whole-cell lysates and mitochondrial and cytosolic fractions were then harvested. Protein levels of (A) p-BAD, BAD and Bcl-2, (B) Apaf-1 and (C) caspase-9, caspase-3 and caspase-7 signals were determined by western blot analysis. $\beta$-actin was an internal loading control. (D) The cytosolic (top) and mitochondrial (bottom) fractions were used to determine for cytochrome $c$ translocation by western blot analysis. GAPDH and COX IV were internal loading controls. (E) Following pre-incubation with or without $10 \mu \mathrm{M} \mathrm{z}$-VAD-fmk (a pan-caspase inhibitor) for 2 h, the cells were exposed to $30 \mathrm{mM}$ metformin for $48 \mathrm{~h}$. Cell viability was assessed using the MTT assay. The values are presented as the mean \pm standard deviation of triplicates ${ }^{*} \mathrm{P}<0.05$ vs. metformin-treated only. p-, phospho; BAD, Bcl-2-associated agonist of cell death; Bcl-2, B-cell lymphoma-2; Apaf-1, apoptotic protease-activating factor-1; z-VAD-fmk, carbobenzoxyvalyl-alanyl-aspartyl fluoromethyl ketone.

survival $(43,44)$. Activation of AMPK signaling and the attenuation of ERK signaling contribute to the antitumor effects of metformin in MCF-7 breast cancer cells (68). Furthermore, the inhibitory effect of metformin on MAPK activity is involved in protection against atherosclerosis (69). $\mathrm{Lu}$ and $\mathrm{Xu}$ (70) demonstrated that ERK1/2 activation can inhibit cell apoptosis via modulation of tumor necrosis factor, Fas ligand, radiation stress, hypoxia and response to 


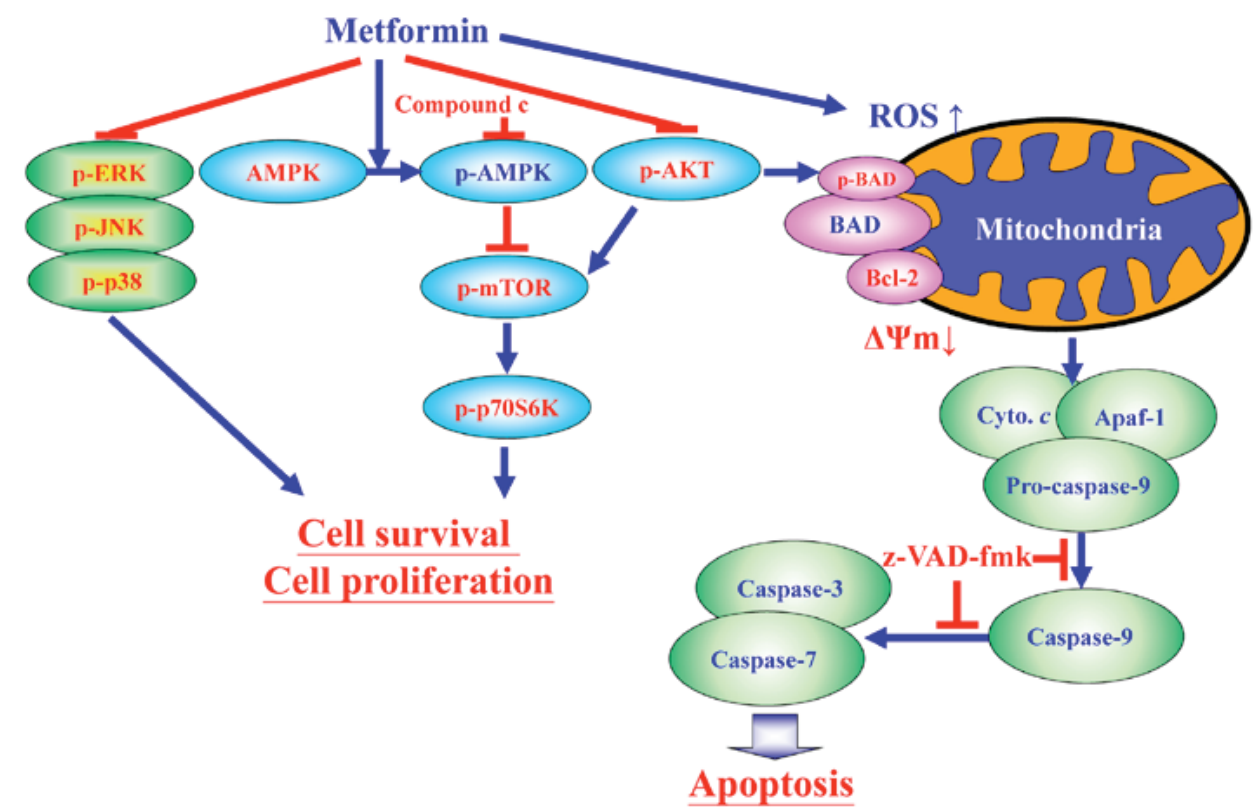

Figure 9. Schematic diagram of an integrated circuit regarding that AMPK, AKT/mTOR, and apoptosis-related molecular machinery caused by metformin in human gastric adenocarcinoma AGS cells. p-, phospho; ERK, extracellular signal-regulated kinase; JNK, c-Jun N-terminal kinase; AMPK, adenosine monophosphate-activated protein kinase; mTOR, mammalian target of rapamycin; p70S6K, ribosomal protein S6 kinase B1; AKT, protein kinase B; ROS reactive oxygen species; BAD, Bcl-2-associated agonist of cell death; Bcl-2, B-cell lymphoma-2; $\Delta \Psi \mathrm{m}$, mitochondrial membrane potential; Cyto. $c$, cytochrome $c$; Apaf-1, apoptotic protease-activating factor-1; z-VAD-fmk, carbobenzoxyvalyl-alanyl-aspartyl fluoromethyl ketone.

increased levels of Bcl-2 and Bcl-xL in response to DNA damage and stress $(73,74)$. The current study demonstrated that metformin-induced apoptosis may be mediated via downregulation of ERK, JNK and p38 phosphorylation, and Bcl-2 expression in AGS cells. Phosphorylation of MAPKs may be involved in Bcl-2 modulation in metformin-induced apoptosis of AGS cells. Additionally, metformin was previously reported to inhibit the invasion of human hepatocellular carcinoma cells via downregulation of ERK/JNK-mediated nuclear factor- $x \mathrm{~B}$-dependent signaling (75). The findings of the current study are in accordance with previous reports, and suggesting that metformin-suppressed cell growth is associated with AMPK-modulated AKT/mTOR and MAPK signaling pathways.

Wang et al (76) and Gao et al (77) have reported that metformin induces mitochondria-dependent apoptosis in human lung adenocarcinoma A549 cells and in human MDA-MB-231 and MDA-MB-435 breast cancer cells. Energy disruptors and AMPK activation lead to mitochondria-dependent apoptosis. Metformin is an energy disruptor and activator of AMPK $(76,77)$. The current study investigated apoptosis induction and mitochondria-dependent pathway by ROS production, and the protein expression levels of pro- and anti-apoptotic proteins in metformin-treated AGS cells. The results suggest that metformin promotes caspase-dependent mitochondria-derived apoptosis in AGS cells and are in agreement with the previous study by Xiong et al (49).

Metformin has been established to exhibit clinical efficacy in conditions characterized by hyperinsulinemia, including polycystic ovarian syndrome, gestational diabetes, non-alcoholic steatohepatitis and pre-diabetes (78). Anticancer effects of metformin have been reported in various cancer types. In non-small cell lung cancer, metformin monotreatment or combined treatment resulted in decreased cell proliferation and increased apoptotic death (79). In colorectal cancer (CRC), metformin was demonstrated to interfere with the EMT process (80). Patients with T2D treated with metformin exhibited a lower rate of CRC than non-metformin users, with a statistically significant cumulative tumor-free survival (81). In breast cancer, cell growth was reduced by targeting the AMPK signaling pathway (82). The results of the present study suggested that metformin may be a promising therapy for human gastric adenocarcinoma and useful as an adjunct to other chemotherapies. There are two molecular actions of metformin can be implicated in anticancer actions (29): i) By decreasing insulinemia and glycemia action, metformin can block the PI3K/MAPKs signaling pathway, which are implicated in cancer cell growth (81); and ii) metformin can directly act on cancer cells by targeting various processes, including tumor cell metabolism, inflammation, angiogenesis and cancer stem cells, via the activation of the AMPK pathway $(36,81)$. Metformin may become an alternative cancer adjuvant therapy, providing a novel approach for cancer prevention and treatment.

In conclusion, the findings of the current study provide an understanding of the mechanisms of metformin that can induce apoptosis of AGS cells through AMPK/AKT/mTOR signaling(Fig.9).Itis probablecomplete underlying mechanisms involved and the inhibitory effect of metformin on human gastric adenocarcinoma AGS cells have not been fully elucidated. The present study supports further research on the therapeutic use of metformin in treating human gastric cancer should be performed in the near future.

\section{Acknowledgements}

We wish to acknowledge the work of Mr. Chang-Wei Li (AllBio Science Incorporated, Taichung, Taiwan) for the 
excellent technique. We also thank Mr. Meng-Jou Liao and Mr. Chin-Chen Lin (Tekon Scientific Corp., Taipei, Taiwan) for their assistance and equipment support on this study.

\section{Funding}

This study was supported by the project (grantno.TCRD107-55) from the Hualien Tzu Chi Hospital (Hualien, Taiwan) and in part by the China Medical University Hospital (Taichung, Taiwan; grant no. DMR-107-123).

\section{Availability of data and materials}

The data sets generated during the study are available from the corresponding author on reasonable request.

\section{Authors' contributions}

CL, JY and HC conceived and designed the experiments. JC, YH and YJ performed the experiments. CL, FT and JY analyzed the data. CL, JY and HC wrote and modified the paper. All authors read and approved the final manuscript.

\section{Ethics approval and consent}

Not applicable.

\section{Patient consent for publication}

Not applicable.

\section{Competing interests}

The authors declare that they have no competing interests.

\section{References}

1. Newell M, Baker K, Postovit LM and Field CJ: A critical review on the effect of docosahexaenoic acid (DHA) on cancer cell cycle progression. Int J Mol Sci 18: 18, 2017.

2. Ministry of Health and Welfare: Republic of China (Taiwan). https://goo.gl/K1mgSD. 2018.

3. Lee YY and Derakhshan MH: Environmental and lifestyle risk factors of gastric cancer. Arch Iran Med 16: 358-365, 2013.

4. Khatoon J, Rai RP and Prasad KN: Role of Helicobacter pylori in gastric cancer: Updates. World J Gastrointest Oncol 8: 147-158, 2016.

5. American Cancer Society: https://goo.gl/QdHTvk. 2018.

6. Tebbutt NC, Cummins MM, Sourjina T, Strickland A, Van Hazel G, Ganju V, Gibbs D, Stockler M, Gebski V and Zalcberg J; Australasian Gastro-Intestinal Trials Group: Randomised, non-comparative phase II study of weekly docetaxel with cisplatin and 5-fluorouracil or with capecitabine in oesophagogastric cancer: The AGITG ATTAX trial. Br J Cancer 102: 475-481, 2010.

7. Wöhrer SS, Raderer M and Hejna M: Palliative chemotherapy for advanced gastric cancer. Ann Oncol 15: 1585-1595, 2004

8. Hou YC, Hu Q, Huang J, Fang JY and Xiong H: Metformin therapy and the risk of colorectal adenoma in patients with type 2 diabetes: A meta-analysis. Oncotarget 8: 8843-8853, 2017.

9. Castilla-Guerra L, Fernandez-Moreno MD, Leon-Jimenez D and Carmona-Nimo E: Antidiabetic drugs and stroke risk. Current evidence. Eur J Intern Med 48: 1-5, 2018.

10. Coughlan KA, Valentine RJ, Ruderman NB and Saha AK: AMPK activation: A therapeutic target for type 2 diabetes? Diabetes Metab Syndr Obes 7: 241-253, 2014.
11. Nyane NA, Tlaila TB, Malefane TG, Ndwandwe DE and Owira PM: Metformin-like antidiabetic, cardio-protective and non-glycemic effects of naringenin: Molecular and pharmacological insights. Eur J Pharmacol 803: 103-111, 2017.

12. Zheng J, Woo SL, Hu X, Botchlett R, Chen L, Huo Y and Wu C Metformin and metabolic diseases: A focus on hepatic aspects. Front Med 9: 173-186, 2015.

13. Mallik R and Chowdhury TA: Metformin in cancer. Diabetes Res Clin Pract 143: 409-419, 2018.

14. Bridgeman SC, Ellison GC, Melton PE, Newsholme P and Mamotte CD: Epigenetic effects of metformin: From molecular mechanisms to clinical implications. Diabetes Obes Metab 20: 1553-1562, 2018

15. Tan M, Wu A, Liao N, Liu M, Guo Q, Yi J, Wang T, Huang Y, Qiu B and Zhou W: Inhibiting ROS-TFE3-dependent autophagy enhances the therapeutic response to metformin in breast cancer. Free Radic Res 52: 872-886, 2018.

16. Amaral I, Silva C, Correia-Branco A and Martel F: Effect of metformin on estrogen and progesterone receptor-positive (MCF-7) and triple-negative (MDA-MB-231) breast cancer cells. Biomed Pharmacother 102: 94-101, 2018.

17. Fransgaard T, Thygesen LC and Gögenur I: Association between metformin use after surgery for colorectal cancer and oncological outcomes: A nationwide register-based study. Int J Cancer 143: 63-72, 2018.

18. Cai X, Hu X, Cai B, Wang Q, Li Y, Tan X, Hu H, Chen X, Huang J, Cheng J, et al: Metformin suppresses hepatocellular carcinoma cell growth through induction of cell cycle G1/G0 phase arrest and p21CIP and p27KIP expression and downregulation of cyclin D1 in vitro and in vivo. Oncol Rep 30: 2449-2457, 2013.

19. Xia C, Liang S, He Z, Zhu X, Chen R and Chen J: Metformin, a first-line drug for type 2 diabetes mellitus, disrupts the MALAT1/miR-142-3p sponge to decrease invasion and migration in cervical cancer cells. Eur J Pharmacol 830: 59-67, 2018.

20. Bai M, Yang L, Liao H, Liang X, Xie B, Xiong J, Tao X, Chen X, Cheng Y, Chen X, et al: Metformin sensitizes endometrial cancer cells to chemotherapy through IDH1-induced Nrf2 expression via an epigenetic mechanism. Oncogene 37: 5666-5681, 2018

21. Kheirandish M, Mahboobi H, Yazdanparast M, Kamal W and Kamal MA: Anticancer effects of metformin: Recent evidences for its role in prevention and treatment of cancer. Curr Drug Metab 19: 793-797, 2018.

22. Lacroix O, Couttenier A, Vaes E, Cardwell CR, De Schutter H and Robert A: Impact of metformin on gastric adenocarcinoma survival: A Belgian population based study. Cancer Epidemiol 53: 149-155, 2018.

23. Wu Y, Gao WN, Xue YN, Zhang LC, Zhang JJ, Lu SY, Yan XY, Yu HM, Su J and Sun LK: SIRT3 aggravates metformin-induced energy stress and apoptosis in ovarian cancer cells. Exp Cell Res 367: 137-149, 2018.

24. Sun S, Gong F, Liu P and Miao Q: Metformin combined with quercetin synergistically repressed prostate cancer cells via inhibition of VEGF/PI3K/Akt signaling pathway. Gene 664: 50-57, 2018.

25. Lu R, Yang J, Wei R, Ke J, Tian Q, Yu F, Liu J, Zhang J and Hong T: Synergistic antitumor effects of liraglutide with metformin on pancreatic cancer cells. PLoS One 13: e0198938, 2018

26. Wei M, Mao S, Lu G, Li L, Lan X, Huang Z, Chen Y, Zhao M, Zhao Y and Xia Q: Valproic acid sensitizes metformin-resistant human renal cell carcinoma cells by upregulating $\mathrm{H} 3$ acetylation and EMT reversal. BMC Cancer 18: 434, 2018

27. Peng M, Darko KO, Tao T, Huang Y, Su Q, He C, Yin T, Liu Z and Yang X: Combination of metformin with chemotherapeutic drugs via different molecular mechanisms. Cancer Treat Rev 54: 24-33, 2017

28. Sośnicki S, Kapral M and Węglarz L: Molecular targets of metformin antitumor action. Pharmacol Rep 68: 918-925, 2016.

29. Daugan M, Dufaÿ Wojcicki A, d'Hayer B and Boudy V: Metformin: An anti-diabetic drug to fight cancer. Pharmacol Res 113: 675-685, 2016.

30. Chen G, Feng W, Zhang S, Bian K, Yang Y, Fang C, Chen M, Yang J and Zou X: Metformin inhibits gastric cancer via the inhibition of HIF1 $\alpha /$ PKM2 signaling. Am J Cancer Res 5: 1423-1434, 2015.

31. Dorn GW II: Molecular mechanisms that differentiate apoptosis from programmed necrosis. Toxicol Pathol 41: 227-234, 2013.

32. Fulda S: The mechanism of necroptosis in normal and cancer cells. Cancer Biol Ther 14: 999-1004, 2013.

33. Baig S, Seevasant I, Mohamad J, Mukheem A, Huri HZ and Kamarul T: Potential of apoptotic pathway-targeted cancer therapeutic research: Where do we stand? Cell Death Dis 7: e2058, 2016. 
34. Courtois S, Durán RV, Giraud J, Sifré E, Izotte J, Mégraud F, Lehours $\mathrm{P}$, Varon $\mathrm{C}$ and Bessède $\mathrm{E}$ : Metformin targets gastric cancer stem cells. Eur J Cancer 84: 193-201, 2017.

35. Han G, Gong H, Wang Y,GuoS andLiu K:AMPK/mTOR-mediated inhibition of survivin partly contributes to metformin-induced apoptosis in human gastric cancer cell. Cancer Biol Ther 16: 77-87, 2015.

36. Valaee S, Yaghoobi MM and Shamsara M: Metformin inhibits gastric cancer cells metastatic traits through suppression of epithelial-mesenchymal transition in a glucose-independent manner. PLoS One 12: e0174486, 2017.

37. Lu CC, Huang BR, Liao PJ and Yen GC: Ursolic acid triggers nonprogrammed death (necrosis) in human glioblastoma multiforme DBTRG-05MG cells through MPT pore opening and ATP decline. Mol Nutr Food Res 58: 2146-2156, 2014.

38. Lu CC, Yang JS, Chiang JH, Hour MJ, Lin KL, Lee TH and Chung JG: Cell death caused by quinazolinone HMJ-38 challenge in oral carcinoma CAL 27 cells: Dissections of endoplasmic reticulum stress, mitochondrial dysfunction and tumor xenografts. Biochim Biophys Acta 1840: 2310-2320, 2014.

39. Chang HP, Lu CC, Chiang JH, Tsai FJ, Juan YN, Tsao JW, Chiu HY and Yang JS: Pterostilbene modulates the suppression of multidrug resistance protein 1 and triggers autophagic and apoptotic mechanisms in cisplatin-resistant human oral cancer CAR cells via AKT signaling. Int J Oncol 52: 1504-1514, 2018.

40. Ma YS, Weng SW, Lin MW, Lu CC, Chiang JH, Yang JS, Lai KC, Lin JP, Tang NY, Lin JG, et al: Antitumor effects of emodin on LS1034 human colon cancer cells in vitro and in vivo: Roles of apoptotic cell death and LS1034 tumor xenografts model. Food Chem Toxicol 50: 1271-1278, 2012.

41. Lu CC, Yang JS, Chiang JH, Hour MJ, Lin KL, Lin JJ, Huang WW, Tsuzuki M, Lee TH and Chung JG: Novel quinazolinone MJ-29 triggers endoplasmic reticulum stress and intrinsic apoptosis in murine leukemia WEHI-3 cells and inhibits leukemic mice. PLoS One 7: e36831, 2012.

42. Motoshima H, Goldstein BJ, Igata M and Araki E: AMPK and cell proliferation - AMPK as a therapeutic target for atherosclerosis and cancer. J Physiol 574: 63-71, 2006.

43. Eblen ST: Extracellular-regulated kinases: Signaling from Ras to ERK substrates to control biological outcomes. Adv Cancer Res 138: 99-142, 2018.

44. Peluso I, Yarla NS, Ambra R, Pastore G and Perry G: MAPK signalling pathway in cancers: Olive products as cancer preventive and therapeutic agents. Semin Cancer Biol: Sep 11, 2017 (Epub ahead of print). doi: 10.1016/j.semcancer.2017.09.002

45. Bailey CJ: Metformin: Historical overview. Diabetologia 60: 1566-1576, 2017.

46. Kinaan M, Ding H and Triggle CR: Metformin: An old drug for the treatment of diabetes but a new drug for the protection of the endothelium. Med Princ Pract 24: 401-415, 2015.

47. Seliger C, Meyer AL, Renner K, Leidgens V, Moeckel S, Jachnik B, Dettmer K, Tischler U, Gerthofer V, Rauer L, et al: Metformin inhibits proliferation and migration of glioblastoma cells independently of TGF- $\beta 2$. Cell Cycle 15: 1755-1766, 2016.

48. Li P, Zhang C, Gao P, Chen X, Ma B, Yu D, Song Y and Wang Z: Metformin use and its effect on gastric cancer in patients with type 2 diabetes: A systematic review of observational studies. Oncol Lett 15: 1191-1199, 2018.

49. Xiong Y, Lu QJ, Zhao J and Wu GY: Metformin inhibits growth of hepatocellular carcinoma cells by inducing apoptosis via mitochondrion-mediated pathway. Asian Pac J Cancer Prev 13: 3275-3279, 2012

50. Tang G, Guo J, Zhu Y, Huang Z, Liu T, Cai J, Yu L and Wang Z: Metformin inhibits ovarian cancer via decreasing H3K27 trimethylation. Int J Oncol 52: 1899-1911, 2018.

51. Huo J, Bian XH, Huang Y, Miao ZC and Song LH: Inhibitory effect and mechanism of metformin on human ovarian cancer cells SKOV-3 and A2780. Eur Rev Med Pharmacol Sci 21: 484-489, 2017.

52. Dos Santos Guimarães I, Ladislau-Magescky T, Tessarollo NG, Dos Santos DZ, Gimba ERP, Sternberg C, Silva IV and Rangel LBA: Chemosensitizing effects of metformin on cisplatin- and paclitaxel-resistant ovarian cancer cell lines. Pharmacol Rep 70: 409-417, 2018.

53. Tomic T, Botton T, Cerezo M, Robert G, Luciano F, Puissant A, Gounon P, Allegra M, Bertolotto C, Bereder JM, et al: Metformin inhibits melanoma development through autophagy and apoptosis mechanisms. Cell Death Dis 2: e199, 2011.

54. Liang X, Kong P, Wang J, Xu Y, Gao C and Guo G: Effects of metformin on proliferation and apoptosis of human megakaryoblastic Dami and MEG-01 cells. J Pharmacol Sci 135: 14-21, 2017.
55. Madera D, Vitale-Cross L, Martin D, Schneider A, Molinolo AA, Gangane N, Carey TE, McHugh JB, Komarck CM, Walline HM, et al: Prevention of tumor growth driven by PIK3CA and HPV oncogenes by targeting mTOR signaling with metformin in oral squamous carcinomas expressing OCT3. Cancer Prev Res (Phila) 8: 197-207, 2015.

56. Li Z, Wang L, Luo N, Zhao Y, Li J, Chen Q and Tian Y: Metformin inhibits the proliferation and metastasis of osteosarcoma cells by suppressing the phosphorylation of Akt. Oncol Lett 15: 7948-7954, 2018.

57. Cheng K and Hao M: Metformin inhibits TGF- $\beta 1$-induced epithelial-to-mesenchymal transition via PKM2 relativemTOR/p70s6k signaling pathway in cervical carcinoma cells. Int J Mol Sci 17: 17, 2016

58. He Y, Tan X, Hu H, Wang Q, Hu X, Cai X, Guan Y, Chen B and Jing X: Metformin inhibits the migration and invasion of esophageal squamous cell carcinoma cells by downregulating the protein kinase B signaling pathway. Oncol Lett 15: 2939-2945, 2018.

59. Mussin N, Oh SC, Lee KW, Park MY, Seo S, Yi NJ, Kim H, Yoon KC, Ahn SW, Kim HS, et al: Sirolimus and metformin synergistically inhibits colon cancer in vitro and in vivo. J Korean Med Sci 32: 1385-1395, 2017

60. Rasouli S and Zarghami N: Synergistic growth inhibitory effects of chrysin and metformin combination on breast cancer cells through hTERT and cyclin D1 suppression. Asian Pac J Cancer Prev 19: 977-982, 2018

61. Zhang JW, Zhao F and Sun Q: Metformin synergizes with rapamycin to inhibit the growth of pancreatic cancer in vitro and in vivo. Oncol Lett 15: 1811-1816, 2018.

62. Yi Y, Gao L, Wu M, Ao J, Zhang C, Wang X, Lin M, Bergholz J, Zhang Y and Xiao ZJ: Metformin sensitizes leukemia cells to vincristine via activation of AMP-activated protein kinase. J Cancer 8: 2636-2642, 2017.

63. Zhang HH, Zhang Y, Cheng YN, Gong FL, Cao ZQ, Yu LG and Guo XL: Metformin incombination with curcumin inhibits the growth, metastasis, and angiogenesis of hepatocellular carcinoma in vitro and in vivo. Mol Carcinog 57: 44-56, 2018.

64. Bi T, Zhu A, Yang X, Qiao H, Tang J, Liu Y and Lv R: Metformin synergistically enhances antitumor activity of cisplatinin gallbladder cancer via the PI3K/AKT/ERK pathway. Cytotechnology 70: 439-448, 2018.

65. Zhang Q, Kong J, Dong S, Xu W and Sun W: Metformin exhibits the anti-proliferation and anti-invasion effects in hepatocellular carcinoma cells after insufficient radiofrequency ablation. Cancer Cell Int 17: 48, 2017.

66. Zakikhani M, Dowling R, Fantus IG, Sonenberg N and Pollak M: Metformin is an AMP kinase-dependent growth inhibitor for breast cancer cells. Cancer Res 66: 10269-10273, 2006.

67. Jiang W, Zhu Z and Thompson HJ: Dietary energy restriction modulates the activity of AMP-activated protein kinase, Akt, and mammalian target of rapamycin in mammary carcinomas, mammary gland, and liver. Cancer Res 68: 5492-5499, 2008.

68. Malki A and Youssef A: Antidiabetic drug metformin induces apoptosis in human MCF breast cancer via targeting ERK signaling. Oncol Res 19: 275-285, 2011.

69. Eriksson L and Nyström T: Activation of AMP-activated protein kinase by metformin protects human coronary artery endothelial cells against diabetic lipoapoptosis. Cardiovasc Diabetol 13: 152, 2014.

70. Lu Z and Xu S: ERK1/2 MAP kinases in cell survival and apoptosis. IUBMB Life 58: 621-631, 2006.

71. Potapova O, Anisimov SV, Gorospe M, Dougherty RH, Gaarde WA, Boheler KR and Holbrook NJ: Targets of c-Jun $\mathrm{NH}(2)$-terminal kinase 2-mediated tumor growth regulation revealed by serial analysis of gene expression. Cancer Res 62: 3257-3263, 2002

72. Subramanian M and Shaha C: Up-regulation of Bcl-2 through ERK phosphorylation is associated with human macrophage survival in an estrogen microenvironment. J Immunol 179: 2330-2338, 2007.

73. Flacke JP, Kumar S, Kostin S, Reusch HP and Ladilov Y: Acidic preconditioning protects endothelial cells against apoptosis through p38- and Akt-dependent Bcl-xL overexpression. Apoptosis 14: 90-96, 2009.

74. Kim MJ, Choi SY, Park IC, Hwang SG, Kim C, Choi YH, Kim H, Lee KH and Lee SJ: Opposing roles of c-Jun NH2-terminal kinase and p38 mitogen-activated protein kinase in the cellular response to ionizing radiation in human cervical cancer cells. Mol Cancer Res 6: 1718-1731, 2008 
75. Hsieh SC, Tsai JP, Yang SF, Tang MJ and Hsieh YH: Metformin inhibits the invasion of human hepatocellular carcinoma cells and enhances the chemosensitivity to sorafenib through a downregulation of the ERK/JNK-mediated NF- $x$ B-dependent pathway that reduces uPA and MMP-9 expression. Amino Acids 46: 2809-2822, 2014.

76. Wang J, Gao Q, Wang D, Wang Z and Hu C: Metformin inhibits growth of lung adenocarcinoma cells by inducing apoptosis via the mitochondria-mediated pathway. Oncol Lett 10: 1343-1349, 2015.

77. Gao ZY, Liu Z, Bi MH, Zhang JJ, Han ZQ, Han X, Wang HY, Sun GP and Liu H: Metformin induces apoptosis via a mitochondria-mediated pathway in human breast cancer cells in vitro. Exp Ther Med 11: 1700-1706, 2016.

78. Inzucchi SE, Bergenstal RM, Buse JB, Diamant M, Ferrannini E, Nauck M, Peters AL, Tsapas A, Wender R and Matthews DR: Management of hyperglycemia in type 2 diabetes, 2015: A patient-centered approach: update to a position statement of the American Diabetes Association and the European Association for the Study of Diabetes. Diabetes Care 38: 140-149, 2015
79. Yousef $\mathrm{M}$ and Tsiani E: Metformin in Lung Cancer: Review of in vitro and in vivo animal studies. Cancers (Basel) 9: 9, 2017.

80. Wang $\mathrm{Y}, \mathrm{Wu} \mathrm{Z}$ and $\mathrm{Hu} \mathrm{L}$ : Epithelial-mesenchymal transition phenotype, metformin, and survival for colorectal cancer patients with diabetes mellitus II. Gastroenterol Res Pract 2017: 2520581, 2017.

81. Su T, Liao B, Dong Y, Peng Z, Zhou Q, Li B, Peng S and Zhang N: Effect of metformin on colorectal carcinoma in type 2 diabetes mellitus patients: A Markov model analysis. Zhonghua Wei Chang Wai Ke Za Zhi 20: 689-693, 2017 (In Chinese).

82. Zhang J, Li G, Chen Y, Fang L, Guan C, Bai F, Ma M, Lyu J and Meng QH: Metformin inhibits tumorigenesis and tumor growth of breast cancer cells by upregulating miR-200c but downregulating AKT2 expression. J Cancer 8: 1849-1864, 2017.

(†) $\odot$ This work is licensed under a Creative Commons Attribution-NonCommercial-NoDerivatives 4.0 International (CC BY-NC-ND 4.0) License. 